\title{
PRELIMINARY STUDY INTO THE DECOLORIZATION OF SELECTED DYES BY THE OZONE APPLICATION
}

\author{
Kristína GERULOVÁ ${ }^{1}$, Zuzana SANNY ${ }^{1}$, Alexandra KUCMANOVÁ ${ }^{1}$, \\ Eva BURANSKÁ ${ }^{1}$
}

\author{
${ }^{1}$ Slovak University OF TECHNOLOGY IN BRATISLAVA \\ FACULTY OF MATERIALS SCIENCE AND TECHNOLOGY IN TRNAVA \\ INSTITUTE OF INTEGRATED SAFETY \\ Ulica JÁNA BotTu 2781/25, 91724 TRNAVA, SLOVAK REPUBLIC \\ e-mail: kristina.gerulova@stuba.sk, zuzana.sanny@stuba.sk, \\ alexandra.kucmanova@stuba.sk, eva.buranska@stuba.sk \\ Received 19 April 2021, Accepted 27 May 2021, Published 20 July 2021
}

\begin{abstract}
Synthetic dyes widely used in many kinds of industry affect the colour of wastewater when released to environment due to insufficient treatment in typical sewage treatment plants. Only a small dose of those dyes may significantly affect colour of water and, according to the chemical composition, may pose risks to wildlife and humans. In the research described in this study, decolorization of three various dyes was investigated. Since colour removal of Congo Red such as Methylene blue using ozone have been reported by several authors, and the literature on Naphthol Green B is rather limited, in the present study we compare the decolorization rate of $C R, M B$ and $N G B$. The colour removal occurred quickly and more than 90\% of colour reduction was achieved within 3-6 minutes throughout all tested pH of the solution.
\end{abstract}

\section{Keywords}

Dyes, decolorization, ozone, AOPs, water treatment

\section{INTRODUCTION}

Dyes are organic compounds that are used on textiles, food, silk, wool and other materials. Paints are able to fix permanently on fabrics/objects and are resistant to water, soap, light, acids and alkalis [2]. Organic dyes are widely used in the textile industry, printing and manufacturing. Large amounts of coloured the toxic, non-biodegradable and carcinogenic wastewater are discharged into the environment every year, and cause serious environmental problems [3]. Azo dyes playing a vital role in textile dyes, consist of $70 \%$ of all organic dyes. Various synthetic 
dyes, as well as azo dyes, do not decompose easily in a conventional manner [4]. A dye concentration of only $1.0 \mathrm{mg}$ per Litre adds colour to wastewater [5].

\section{Classification of dyes}

Based on the origin of the material, dyes are classified as natural (natural sources such as plants, animals, including hematoxylin, carmine and orcein) and synthetic (organic, inorganic compounds)[6]. Based on the charge of the particles, they are divided into ionic (cationic and anionic dyes) and non-ionic. Ionic dyes generally pose a higher risk, which is due to their reactivity and carcinogenic nature [5, 7]. According to their colour and the functional group attached to the chemical structure, there exist chromophore dyes (azo, anthraquinone, indigo, xanthenes, phthalocyanine, nitrated, and nitrosated and triphenylmethane dyes) or auxochrome dyes (they contain acid or anionic dyes, basic or cationic dyes, vat dyes, direct dyes, mordant dyes, reactive dyes, azo dyes, and dispersed dyes) [3, 6, 8].

Methylene Blue (MB) may be also referred to as Basic blue 9. It is a cationic dye. Chemical structure is presented in Figure 1. It was developed in 1876 as a dye for the textile industry, and later became the first synthetic drug used in medicine [9, 10]. It has harmful effects on the environment and human health. It causes high blood pressure, fever, redness of skin, irritation of the throat, mouth, oesophagus and stomach, gastrointestinal pain, nausea, vomiting, diarrhoea, dizziness, headache and fever [11].

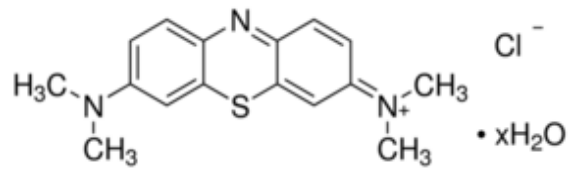

Figure 1 Methylene blue chemical structure, CAS Number: 122965-43-9

Congo Red (CR) which is also referred to as Direct red 28 is one of the most used azo dyes. It is an anionic dye derived from benzidine which is a carcinogen. About $15 \%$ of Congo red in the textile, paper and leather industries end up in wastewater [12]. CR pollutes water significantly, and may affect marine life, such as plants and aquatic organisms. In humans, it causes toxicity and diseases such as mutations and respiratory problems [13]. Chemical structure is presented in Figure 2.

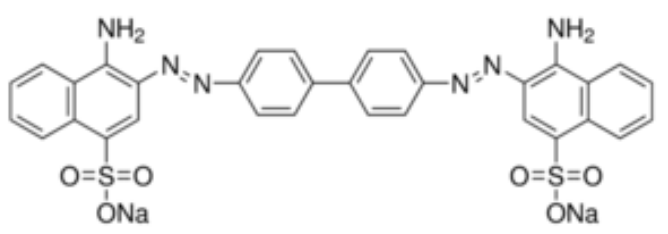

Figure 2 Congo Red chemical structure, CAS Number: 573-58-0

Naphthol Green B (NGB), also referred to as Acid Green 1, is a complex of iron $\left(3^{+}\right)$with 1-nitroso-2-naphthol-6-sulfonic acid (Figure 3) [14]. It is one of the highly soluble anionic dyes, which belongs to the azo dyes, and it is a derivative of naphthenic acid. This dye is mainly used by the textile industry to dye and print wool, nylon, and silk fabrics, which are also used to dye leather [15]. Owing to its low cost and efficiency of electron transfer, NGB acts as a mediator in electro catalysis, especially for dopamine and uric acid, and can also be used in several 
spectrophotometric devices [16]. Naphthol green dye B is dangerous for humans; it may cause health problems such as increased heart rate, shock, and cyanosis [17].

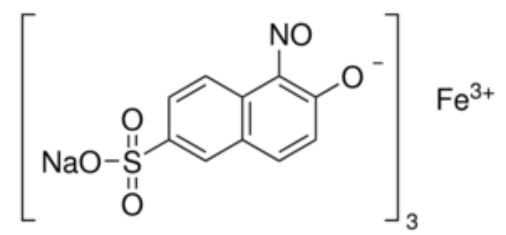

Figure 3 Naphthol Green B chemical structure, CAS Number: 19381-50-1

\section{Treatment of colorant wastewater}

Many physical, chemical and biological techniques are used to remove the adverse effects of dyes, e.g. ozonation, advanced oxidation, electrochemical oxidation, biosorption, reverse osmosis, precipitation, membrane filtration, flocculation/coagulation, adsorption, ultrasonic, photochemical and sonochemical degradation as well as photocatalytic degradation [18].

\section{Ozonation}

Ozone can oxidize the organic and inorganic substances in a water body over a wide $\mathrm{pH}$ range. Ozonation takes place by direct and indirect reactions. In a direct reaction, molecular ozone reacts with organic substances; the reaction takes place at $\mathrm{pH}<4$ [19]. This methodology is highly selective. It attacks the organic compounds with reducible double bonds. Therefore, it is generally more effective when applied to activated amines and aromatic hydrocarbon compounds [20]. The indirect reaction concerns the decomposition of ozone in water to form the $\bullet \mathrm{OH}$ radical, which participates in the oxidation reaction [13] taking place at $\mathrm{pH}>10$ [19]. During ozonation of the colour effluent, ozone initially attacks the unsaturated bonds of the chromophores, providing rapid colour elimination. However, simple ozonation is often not sufficient to completely remove the oxidation by-products such as hydroxyl radicals [21]. Ozone oxidation technology may be more efficient in the destruction of e.g. azo dyes, when combined with other technologies, such as ultraviolet radiation [13] or $\mathrm{H}_{2} \mathrm{O}_{2}[19,22]$.

\section{MATERIALS AND METHODOLOGY OF EXPERIMENT}

All chemicals were analytical grade and employed without any further purification. In these experiments, three dyes (Methylene blue (MB), Naphthol Green B (NGB), and Congo red $(\mathrm{CR})$ ) were used.

\section{Analytical methods}

The concentration of selected dyes in the solution was measured in a $1 \mathrm{~cm}$ cuvette using UV-VIS spectrophotometer (Genesis 8).

\section{Ozonation}

Ozone was produced from air using an OZONFILT ${ }^{\circledR}$ OZVa type 2 ozone generator (Prominent), which can produce up to $15 \mathrm{~g}$ of $\mathrm{O}_{3}$ per hour. Compressed air was supplied as feed gas for the production of ozone at a rate of $20 \mathrm{~L} \mathrm{~min}^{-1}$. The experiment was conducted in a glass reactor $(5 \mathrm{~L})$, and ozone was aerated through a small micro porous diffuser to 1 litre 
of app. $15 \mathrm{mg} \mathrm{L}^{-1}$ of selected dye for 10 minutes maximum. The concentration of the ozone at the output of the generator was $10 \%$ (23 mg per minute). The $\mathrm{pH}$ of the solution was set to the values $3,5,7,9$ and 11 . The experiments were carried out in triplicates.

\section{Dye removal efficiency}

The dye removal efficiency $(\mathrm{R})$ was determined based on the decrease in the concentration of the dye at the beginning and at time $t$, and it was calculated using the following equation (1):

$$
R=\frac{C_{0}-C_{t}}{C_{0}} 100 \%
$$

where $C_{0}$ and $C_{t}\left(\mathrm{mg} \mathrm{L}^{-1}\right)$ were the initial concentration and the concentration of selected dye at $t$.

\section{RESULTS AND DISCUSSION}

The overall reaction kinetics between ozone and the tested dyes (equation 2) were proposed to be of second order with respect to both reactants [23]:

$$
-\frac{d\left[c_{A}\right]}{d t}=\frac{d\left[O_{3}\right]}{d t}=k^{\prime}\left[O_{3}\right]\left[c_{A}\right]
$$

Since the ozone is presented in excess compared to the dye, the rate of dye decay $\left(r_{A}\right)$ could be assumed to follow the pseudo-first order rate kinetics (equation 3):

$$
-r_{A}=-\frac{d\left[c_{A}\right]}{d t}=k\left[c_{A}\right]
$$

The integrated form of the equation is (equation 4):

$$
\ln \left(\frac{c_{A}}{c_{0}}\right)=-k t
$$

where $C_{A}$ is the concentration of the dye at time $t, C_{0}$ is the concentration of the dye before the ozone application, and $k$ is the pseudo-first-order rate constant.

The results obtained in the ozonation of the dyes are displayed in Fig. 4 a-c. The proposed pseudo-first order kinetic model was fitted to the experimental measurements of all tested dyes (Figure 5 a-c); the results are summarized in Figure 6.
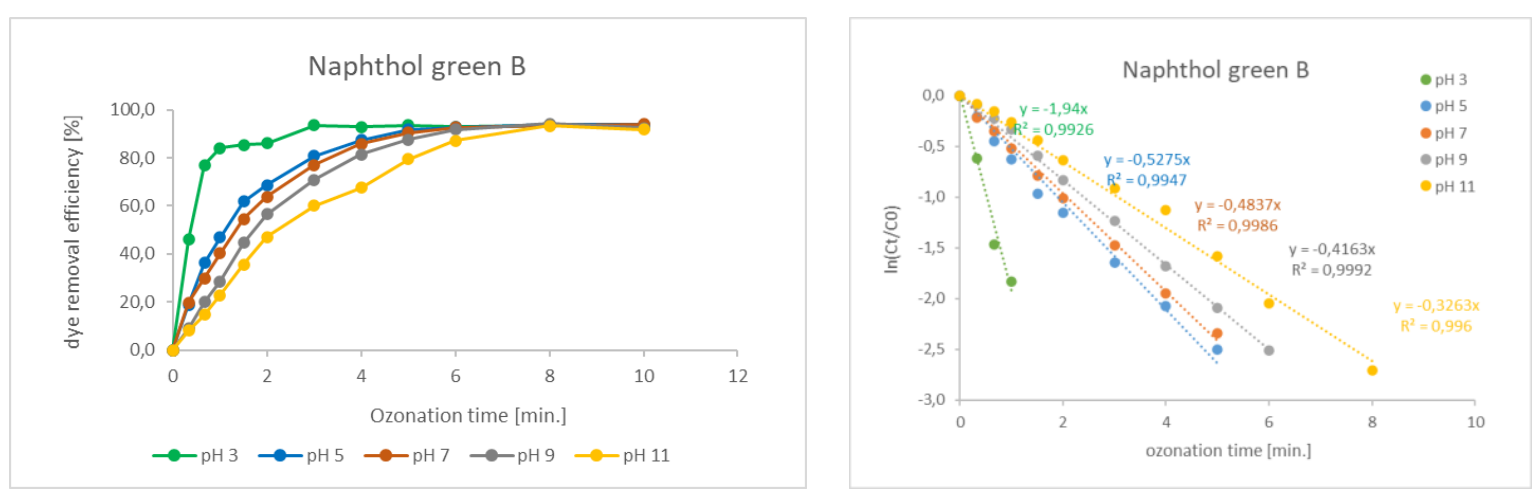

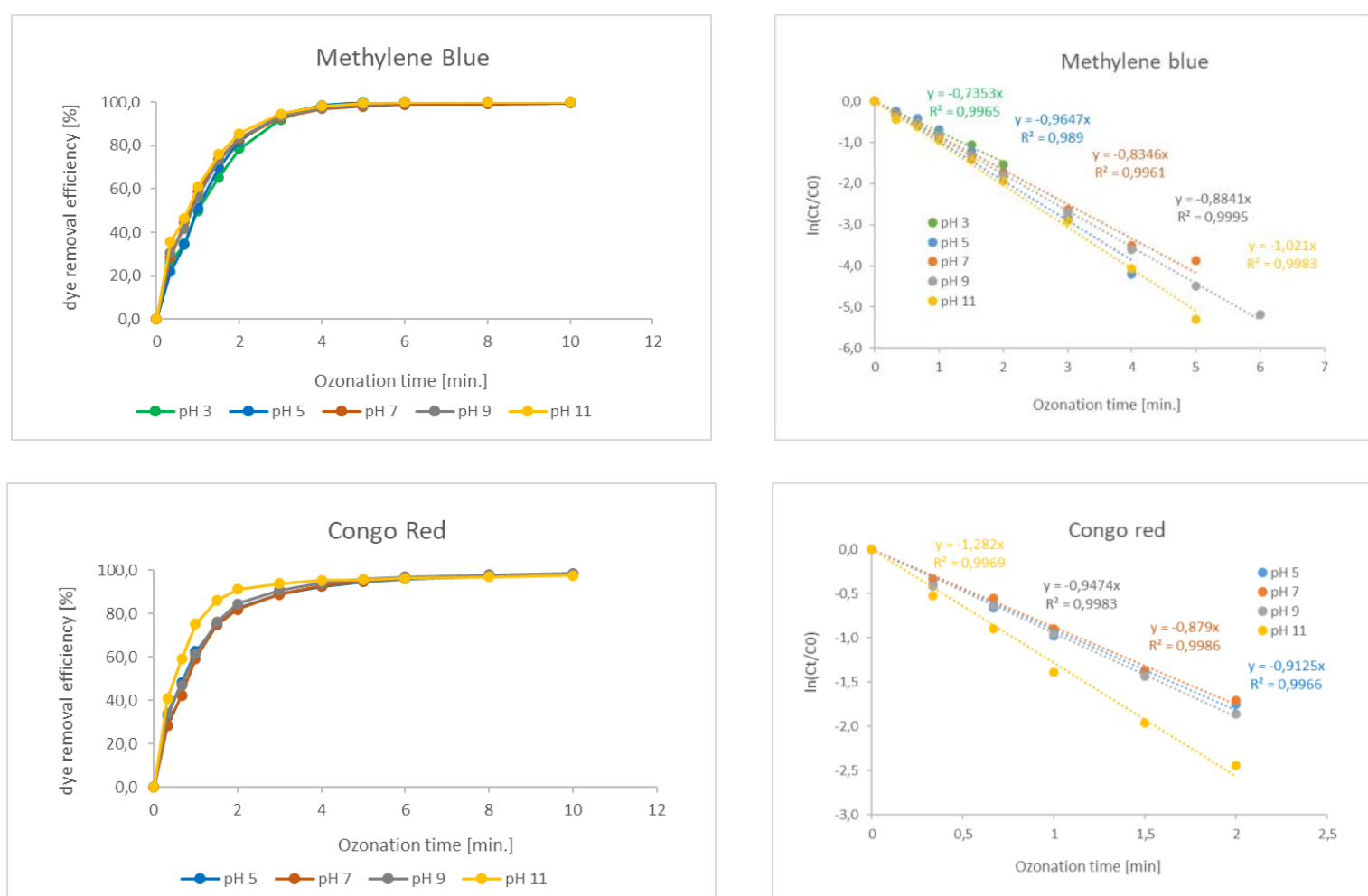

Figure $4 \boldsymbol{a}, \boldsymbol{b}, \boldsymbol{c}$ Colour reduction versus contact time at different $\mathrm{pH}$

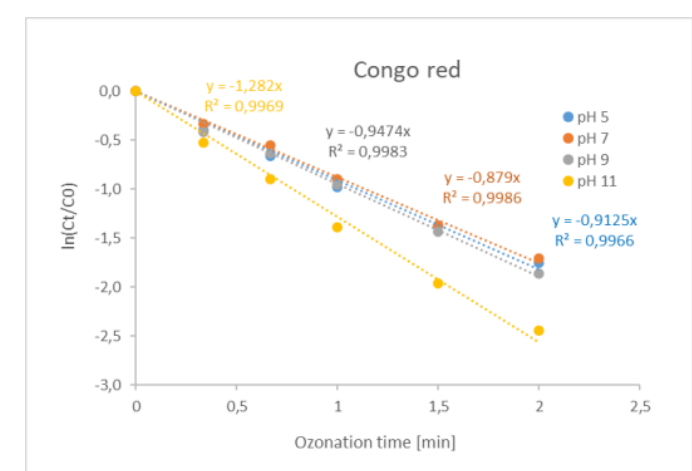

Figure $5 \boldsymbol{a}, \boldsymbol{b}, \boldsymbol{c}$ Rate constant of pseudo-first order kinetic model

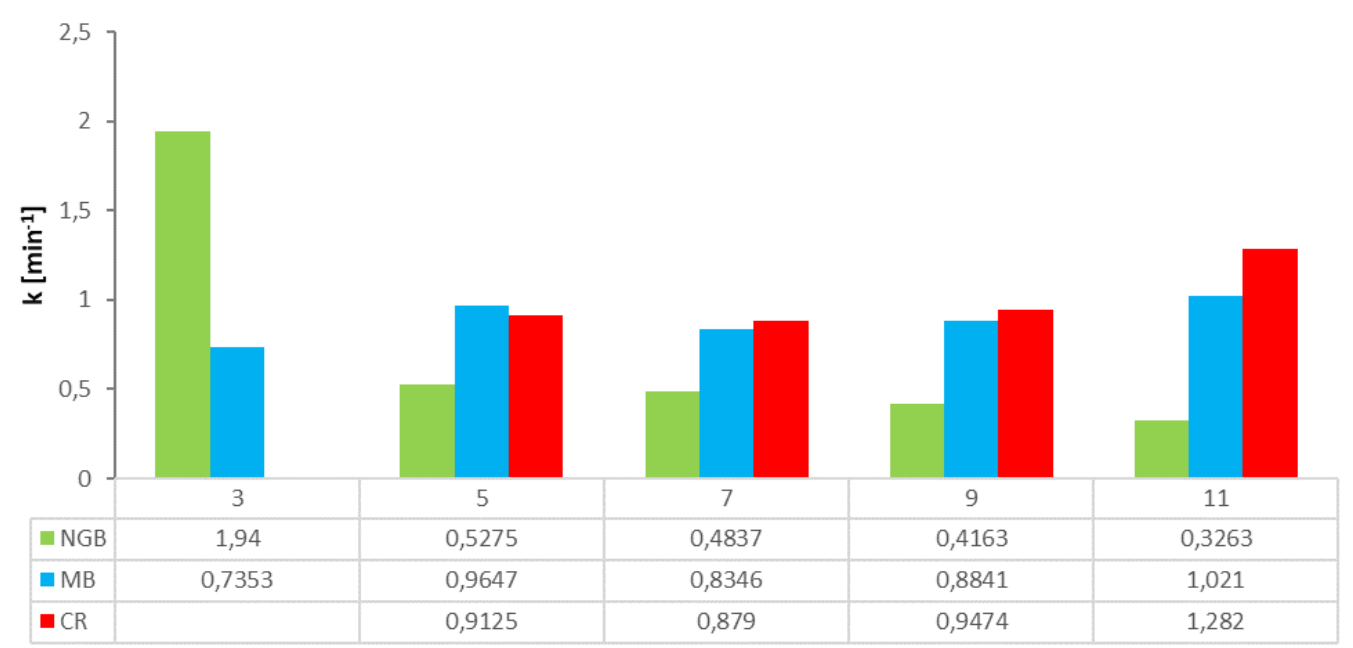

Figure 6 Rate constant of pseudo-first order kinetic model at different $\mathrm{pH}$

The $\mathrm{pH}$ is one of the major factors which may affect treatment efficiency by ozonation. As can be seen in Fig. 4 a-c, the decolorization of all tested dyes occurred very fast, while achieving 97-98 \% for MB, 92-95 \% for CR and 71-92 \% for NGB respectively, after 4 minutes of ozone application. The biggest difference in the colour reduction related to $\mathrm{pH}$ was achieved in the case of NGB where, after two minutes of ozone application, only $47.1 \%$ colour reduction was achieved at $\mathrm{pH} 11$ in comparison to $86.0 \%$ at $\mathrm{pH} 3$. In case of both the MB and CR, the difference of colour reduction within the whole tested range of $\mathrm{pH}$ was not so obvious; e.g., for $\mathrm{MB}$ at $\mathrm{pH} 3$, the colour reduction was $78.4 \%$ at $\mathrm{pH} 3$ and $85.6 \%$ at $\mathrm{pH} \mathrm{11}$, and 82 and $91 \%$ respectively after two minutes of ozonation in the case of CR. After 10 minutes of contact time, 
the reached colour removal efficiency was $97-98 \%$ for CR, 99-100\% for MB, and 92-94\% for NGB respectively.

The efficiency of colour removal increased with increasing $\mathrm{pH}$ in the case of $\mathrm{MB}$ and $\mathrm{CR}$, while in the case of NGB, the colour removal efficiency decreased with increased $\mathrm{pH}$ value.

The decolorization process agreed with the pseudo-first-order reaction kinetics implying a steady state or over-dosed property of ozone concentration, as shown in Fig. 5 a-c. When to compare the rate constant of pseudo-first order kinetic model at different $\mathrm{pH}$, Naphthol green B showed a 2.6-fold higher rate constant at $\mathrm{pH} 3$ when compared to Methylene blue.

The efficiency of colour removal increased with increasing $\mathrm{pH}(\mathrm{pH} 11)$ in the case of $\mathrm{MB}$ (rate constant was 1.021) and CR (rate constant was 1.282), while in the case of NGB, the colour removal efficiency decreased with increased $\mathrm{pH}$ value of the tested solution (rate constant was 0.3263 ).

Positive effect of increased $\mathrm{pH}$ value on the decolorization rate in the case of $\mathrm{MB}$ was previously reported e.g. in [24] or [25]. Adelin et al. in [24] reported that the highest MB dye removal efficiency was observed in the alkaline range. The maximum ozonation of degradation was at $\mathrm{pH} 11$ and $13 \mathrm{~min}$ [24]. Sumegova et al. in [25] performed experiments at $\mathrm{pH} \mathrm{3,7}$

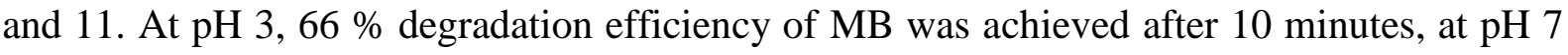
degradation efficiency of MB $71 \%$ was achieved in 10 minutes of ozonation and $90 \%$ efficiency in 10 minutes of ozonation at $\mathrm{pH}$ 11. Similar data were found for CR dye removal. According to Gharbani et.al. and Tapalad et al., to carry out ozonation processes at higher $\mathrm{pH}$, both, ozonation performance as well as colour removal efficiency should be improved. The best results can again be observed for the samples with $\mathrm{pH} 10$ [26] and at $\mathrm{pH} 11$ [27].

According to the well-known fact, that the initial $\mathrm{pH}$ may drop fast [28], when a pH buffer is not used to stabilize the $\mathrm{pH}$ of the tested solution, the positive influence of $\mathrm{pH}$ on the colour removal could be attributed to the presence of reactive $\bullet \mathrm{OH}$ radicals. The hydroxyl radicals are formed from ozone by its decomposition at high $\mathrm{pH}$ values, while the molecular ozone remains as the main oxidant at low $\mathrm{pH}$ values [28]. The first stage of decolourisation occurs through ozone reaction with the double bond azo chromophoric group $-\mathrm{N}=\mathrm{N}-$ or with the double bond of the $-\mathrm{C}=\mathrm{C}-$ connecting aromatic rings. Generally, the decolourisation by ozone occurs rapidly due to the rapid destruction of the conjugated chains of the dye molecules that are responsible for colour [29].

\section{CONCLUSION}

Ozone can reduce colour of different dyes after its application to the solution under specific conditions. At the output of the ozone generator, ozone at the concentration of $23 \mathrm{mg}$ per minute was applied to 1 litre of dye solution. $\mathrm{pH}$ of the dye solution varied from 3 to 11 . The colour removal occurred quickly, and more than $90 \%$ of colour reduction was achieved within 3-6 minutes.

\section{Acknowledgement}

The article was written with the support of the Project of KEGA Grant Agency of the Ministry of Education, Science, Research and Sport of the Slovak Republic No. 020STU-4/2021: Building an innovative teaching laboratory for practical and dynamic education of students in the field of occupational safety and health. 


\section{References}

[1] R. AHMAD, K. ANSARI. 2021. Comparative study for adsorption of congo red and methylene blue dye on chitosan modified hybrid nanocomposite. Process Biochem., Vol. 108, No. May, pp. 90-102.

[2] S. SAMAI. 2020. Dyeiny Process 100, pp. 1-6.

[3] B. CHAUDHARY and T. E. VIOLET. 2020. Chemistry of synthetic dyes: A review. J. Interdiscipl. Cycle Res., XII(390), pp. 390-396.

[4] A. R. QUAFF, S. VENKATESH and K. VENKATESH. 2020. Degradation of Azo Dye by Ozone Oxidation: Cost Analysis and Buffering Effects on Dye Decomposition. Natl. Acad. Sci. Lett., pp. 9-11.

[5] S. K. PANDA et al. 2021. Magnetite nanoparticles as sorbents for dye removal: a review, No. 0123456789. Springer International Publishing.

[6] R. BUSHRA, S. MOHAMAD, Y. ALIAS, Y. JIN and M. AHMAD. 2021. Current approaches and methodologies to explore the perceptive adsorption mechanism of dyes on low-cost agricultural waste: A review. Microporous Mesoporous Mater., p. 111040.

[7] A. KALRA and A. GUPTA. 2020. Recent advances in decolourization of dyes using iron nanoparticles: A mini review. Mater. Today Proc., vol. 36, pp. 689-696.

[8] M. BENJELLOUN, Y. MIYAH, G. AKDEMIR, F. ZERROUQ and S. LAIRINI. 2021. Recent Advances in Adsorption Kinetic Models : Their Application to Dye Types. Arab. J. Chem., 14, (4), p. 103031.

[9] L. THESNAAR, J. J. BEZUIDENHOUT, A. PETZER, J. P. PETZER and T. T. CLOETE. 2020. Methylene blue analogues: In vitro antimicrobial minimum inhibitory concentrations and in silico pharmacophore modelling. Eur. J. Pharm. Sci., vol. 157, No. October 2020.

[10] A. AHMAD, N. KHAN, B. S. GIRI, P. CHOWDHARY and P. CHATURVEDI. 2020. Removal of methylene blue dye using rice husk, cow dung and sludge biochar: Characterization, application, and kinetic studies. Bioresour. Technol., vol. 306, No. January, p. 123202.

[11] F. MASHKOOR and A. NASAR. 2020. Magsorbents: Potential candidates in wastewater treatment technology - A review on the removal of methylene blue dye. J. Magn. Magn. Mater., Vol. 500, No. January, p. 166408.

[12] M. A. ADEBAYO, J. I. ADEBOMI, T. O. ABE, and F. I. AREO. 2020. Removal of aqueous Congo red and malachite green using ackee apple seed-bentonite composite. Colloids Interface Sci. Commun., Vol. 38, No. June, p. 100311.

[13] F. MIRZAEE, A. EKRAMIPOOYA and M. REZA. 2020. Selective separation of Congo Red from a mixture of anionic and cationic dyes using magnetic-MOF : Experimental and DFT study. J. Mol. Liq., Vol. 318, p. 114051.

[14] W. NEUGEBAUER, C. SESSA, C. STEUER, T. ALLSCHER and H. STEGE. 2019. Naphthol Green - a forgotten artists' pigment of the early 20th century. History, chemistry and analytical identification. J. Cult. Herit., Vol. 36, No March, pp. 153-165.

[15] Y. T. HUNG., H. H. P. BUKOLA, M. ADESANMI. 2020. Coagulation-Flocculation Treatment for Naphthol Green Band Flour Wastewater. Int. J. Mod. Trends Sci. Technol., 6(12), pp. 190-197.

[16] E. GUNASUNDARI, P. SENTHIL KUMAR, N. RAJAMOHAN and P. VELLAICHAMY. 2020. Feasibility of naphthol green-b dye adsorption using microalgae: Thermodynamic and kinetic analysis. Desalin. Water Treat., Vol. 192, pp. 358-370.

[17] A. A. ALI, S. R. EL-SAYED, S. A. SHAMA, T. Y. MOHAMED and A. S. AMIN. 2020. Fabrication and characterization of cerium oxide nanoparticles for the removal of naphthol green $b$ dye. Desalin. Water Treat., Vol. 204, pp. 124-135.

[18] M. M. IQBAL et al. 2021. Effective sequestration of Congo red dye with $\mathrm{ZnO/cotton}$ stalks biochar nanocomposite: MODELING, reusability and stability. J. Saudi Chem. Soc., 25(2), p. 101176.

[19] R. RASHID, I. SHAFIQ, P. AKHTER, \& MUHAMMAD, J. IQBAL and M. HUSSAIN. A stateof-the-art review on wastewater treatment techniques: the effectiveness of adsorption method.

[20] N. ATHIKOH, E. YULIANTO, A. W. KINANDANA, E. SASMITA and A. H. SANJANI. 2020. Reduction of Methylene Blue by Using Direct Continuous Ozone. J. Environ. Earth Sci., 10(4), pp. $46-56$. 
[21] J. X. LI, MENGRU, ZHENGLEI HE. 2021. A comparative study of ozonation on aqueous reactive dyes and reactive- dyed cotton. Color. Technol., pp. 1-13.

[22] D. GEORGIOU. 2017. Destruction of Azo-Reactive Dyes by Ozonation and the Synergetic Effect of a Radio-Frequency Alternating Electric Field Inductance Device. Curr. Trends Fash. Technol. Text. Eng., 1(2), pp. 42-47.

[23] M. SHAWAQFAH, F. A. AL MOMANI and Z. A. AL-ANBER. 2012. Ozone treatment of aqueous solutions containing commercial dyes. Afinidad, 69(559), pp. 229-234.

[24] M. A. ADELIN, G. GUNAWAN, M. NUR, A. HARIS, D. S. WIDODO and L. SUYATI. 2020. Ozonation of methylene blue and its fate study using LC-MS/MS. J. Phys. Conf. Ser., 1524(1).

[25] L. SUMEGOVÁ, J. DERCO and M. MELICHER. 2013. Influence of reaction conditions on the ozonation process. Acta Chim. Slovaca, 6(2), pp. 168-172.

[26] T. TAPALAD, A. NERAMITTAGAPONG, S. NERAMITTAGAPONG and M. BOONMEE. 2008. Degradation of congo red dye by ozonation. Chiang Mai J. Sci., 35(1), pp. 63-68.

[27] P. GHARBANI, S. M. TABATABAII and A. MEHRIZAD. 2008. Removal of Congo red from textile wastewater by ozonation. Int. J. Environ. Sci. Technol., 5(4), pp. 495-500.

[28] J. M. ORF, M. FERNANDO and R. PEREIRA. 2006. Ozonation of textile effluents and dye solutions under continuous operation: Influence of operating parameters. Vol. 137, pp. 1664 1673.

[29] C. TIZAOUI and N. GRIMA. 2011. Kinetics of the ozone oxidation of Reactive Orange 16 azodye in aqueous solution. Chem. Eng. J., 173(2), pp. 463-473.

\section{ORCID}

Kristína Gerulová

Zuzana Sanny

Alexandra Kucmanová

Eva Buranská
0000-0003-2588-8627

0000-0003-2079-4277

0000-0003-3089-7712

0000-0002-2382-7508 